\title{
PORTAL AKADEMIK SEMI-REALTIME AMIK DAN STIKOM TUNAS BANGSA PEMATANGSIANTAR
}

\author{
Irfan Sudahri Damani \\ AMIK Tunas Bangsa \\ Jl. Sudirman Blok A No. 1-3, Kota Pematang Siantar, Sumatera Utara 21127 \\ irfansudahri@amiktunasbangsa.ac.id
}

\begin{abstract}
Abstrak - Informasi akademik pada Akademi Manajemen Informatika Komputer (AMIK) Tunas Bangsa Pematangsiantar akan tetap menjadi kebutuhan bagi mahasiswa selama mahasiswa masih aktif dalam proses pendidikan. Hal ini akan sulit diperoleh mengingat jumlah perbandingan jumlah mahasiswa dengan staff yang melayani bidang akademik yang cukup besar. Dengan menggunakan media internet tentu akan mempermudah mahasiswa memperoleh informasi yang di inginkan serta dengan aplikasi yang berbasis database internet, tentu mahasiswa akan memperoleh informasi yang selalu ter-update. Hal ini juga tentu harus didukung oleh aplikasi yang dapat dijalankan oleh dosen pengampu matakuliah dalam hal pengiriman nilai berbasis internet.
\end{abstract}

Keywords-Aplikasi Akademik, internet, mysql online.

\section{PENDAHULUAN}

Pelayanan mengenai informasi mahasiswa merupakan salah satu kegiatan yang rutin menjadi kegiatan sehari hari di bidang akademik. Proses akademik di mulai dari proses kegiatan belajar mengajar, pengisian Kartu rencana studi, Kartu Hasil Studi hingga Ujian perbaikan Nilai. Informasi yang didapat mahasiswa yaitu dengan dating langsung ke bagian akademik untuk mendapatkan informasi tersebut yang tentu saja akan membutuhkan waktu yang lama.

\section{A. Rumusan Masalah}

Bagaimana penyampaian Informasi kepada mahasiswa mengenai Informasi akademik tanpa harus berinteraksi langsung dengan staf akademik.

Bagaimana memperoleh data mahasiswa yang sifatnya dinamis untuk selalu up to date yang dapat dilakukan langsung oleh mahasiswa masing masing.

\section{B. Batasan Masalah}

Aplikasi dirancang menggunakan bahasa pemrograman visual basic 6.0 Enterprise edition, mysql server sebagai database (Freemysql.net) serta mysql connector sebagai provider.

Pembuatan skema flowchart dan pemodelan system menggunakan alat bantu software Microsoft Visio 2003.

\section{Tujuan Penelitian}

Membangun Aplikasi Akademik Online yang dapat digunakan mahasiswa sebagai salah satu fasilitas di AMIK Tunas Bangsa Pematangsiantar secara Online.

Aplikasi ini tidak hanya diharapkan menyajikan informasi akademik, namun dapat melakukan pencetakan Kartu Hasil Studi, Kartu Rencana Studi berupa file pdf serta Upload Foto Mahasiswa berupa file jpg.

\section{Manfaat Penelitian}

Aplikasi Akademik Online ini merupakan suatu sistem yang sangat penting untuk menunjang kecepatan dan ketepatan dalam penyajian informasi tentang informasi akademik yang diperoleh mahasiswa. Jadi, manfaat dari penelitian bagi AMIK Tunas Bangsa Pematangsiantar sendiri yaitu efektifitas tentang informasi nilai serta sebagai bahan dalam pencetakan (KHS) Kartu Hasil Studi. KHS dapat dicetak dengan aplikasi desktop dengan terlebih dahulu melakukan import database dari database mySQL online.

\section{TINJAUAN PUSTAKA}

A. Data

Data Merupakan fakta, gambar atau suara yang mungkin atau tidak berhubungan atau berguna bagi tugas tertentu (Aman, 2011). Data Terdiri dari fakta dan angka yang secara relatif tidak berarti bagi pemakai. Dari kedua pengertian tersebut dapat ditarik kesimpulan bahwa data merupakan segala sesuatu yang dapat diolah sehingga dapat berguna bagi pemakai.

\section{B. Informasi}

Informasi adalah data yang telah diolah menjadi bentuk yang berguna bagi penerimanya dan nyata, berupa nilai yang dapat dipahami didalam keputusan sekarang maupun masa mendatang.(Aman, 2011)

\section{Database}

Database adalah tempat penyimpanan data yang saling berhubungan yang dapat disimpan secara bersama sedemikian rupa dan tanpa pengulangan/redudansi yang tidak perlu untuk 
memenuhi berbagai kebutuhan. Dengan menggunakan database maka institusi ataupun organisasi dapat memperoleh informasi yang relevan, cepat, tepat dan akurat.

\section{Unified Modeling Language}

Pemodelan (modeling) merupakan suatu proses didalam merancang suatu pengkat lunak sebelum dilakukan pengkodean (coding). Semakin komplek sebuah sistem tentu akan semakin dibutuhkan sebuah pemodelan untuk memahami sistem secara menyeluruh dalam merancang sistem tersebut. (Aman, 2011)

Unified Modeling Languange (UML) adalah sistem arstitektur yang mengguanakan object oriented analysis design dengan menggunakan suatu bahasa yang konsisten untuk menspesifisikan, menvisualisasikan, membangun dan mendokumentasikan objek - objek dari sebuah sistem software untuk memodelkan bisnis dan memodelkannya.

Unified Modeling Languange memiliki beberap tujuan, yaitu :

1. Memberikan model yang siap pakai, bahasa pemodelan visual yang ekspresif untuk mengembangkan dan saling menukar model dengan mudah dan dimenegerti umum.

2. Memberikan bahasa pemodelan yang bebas dari berbagai bahasa pemrograman dan proses rekayasa.

3. Menyatukan praktek-praktek yang terbaik yang terdapat dalam pemodelan (Aman, 2010)

\section{METODE PENGAMBILAN DATA}

Adapun metode pengumpulan data dan informasi yang digunakan adalah sebagai berikut:

1. Studi Lapangan (Field Research)

Penelitian yang dilakukan secara langsung ke lapangan atau lokasi penelitian guna melihat secara langsung hal-hal atau data-data yang berkaitan dengan materi yang dibutuhkan.

2. Studi Kepustakaan (Library Research)

Yaitu penelitian yang dilaksanakan berdasarkan data yang diperoleh dari teori-teori yang bisa di dapat dari buku-buku penunjang yang berhubungan dengan topik yang diambil sebagai bahan pembanding atau dasar pembahasan lanjut, serta untuk memperoleh landasan-landasan teori dari sistem yang di kembangkan.

\section{A. Analisa Data}

Data yang diperoleh selanjutnya dianalisis untuk mengembangkan sistem yang ada dengan tujuan memperoleh hasil yang lebih baik lagi.

\section{B. Analisa Kebutuhan}

1) Kebutuhan perangkat keras :

Untuk kebutuhan hardware, penulis menggunakan satu unit PC (Personal komputer) dengan spesifikasi, pentium Intel
Core2Duo 2 Ghz, RAM 2GB, HD 250GB, VGA ati Radeon9200, Monitor 15 Inch.

2) Kebutuhan Perangkat Lunak (Software) : Perangkat lunak yang dipergunakan untuk membangun Aplikasi ini terdiri dari:

- Sistem operasi windows XP

- Visual Basic 6.0

- Mysql Connector

3) Kebutuhan Antar Pemakai (User Interface) : Antarmuka pemakai atau user interface adalah bagian penghubung antara program dengan pengguna. Pengguna akan berhubungan dengan server melalui sebuah program yang dibuat menggunakan bahasa pemrograman Visual Basic 6.0

4) Kebutuhan Input : Kebutuhan input dari Aplikasi adalah sebagai berikut:

- Data Dosen, Data Mahasiswa, Data Kelas, dan Data matakuliah, Data Matriks perkuliahan.

- Data Nilai berdasarkan penilaian yang dilakukan dosen terhadap kehadiran, Tugas, Quis, Ujian Tengah Semester dan Ujian Akhir Semester.

5) Kebutuhan Outpu : Kebutuah output dari Aplikasi akademik adalah sebagai berikut:

- Informasi data nilai hasil belajar berdasarkan kelas mahasiwa untuk matakuliah yang di ampu.

- Informasi Nilai huruf berdasarkan nilai angka yang diperoleh sesuai persentasi masing masing item penilaian

- Kartu hasil studi, kartu rencana studi.

\section{HASIL DAN PENELITIAN}

\section{A. Hasil Analisa Kebutuhan Masalah}

Berdasarkan analisa kebutuhan masalah yang telah di bahas sebelumnya, Aplikasi Akademik Online hasil belajar pada AMIK Tunas Bangsa Pematangsiantar ini berguna sebagai sarana penyampaian laporan oleh dosen mengenai data hasil belajar mahaisswa tiap akhir semester. Dalam sistem ini masalah yang di fokuskan lebih kepada informasi mengenai laporan pencapaian hasil belajar mahasiswa. 


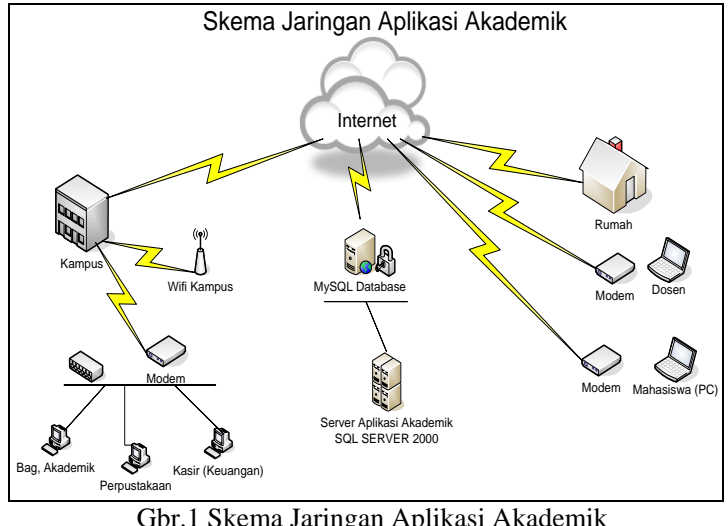

Server Aplikasi Akademik merupakan komputer yang disediakan di kampus Akademi manajemen Informatika (AMIK) Tunas Bangsa pematangsiantar yang berfungsi sebagai server pengolah data akademik. Administrator menggunakan komputer ini untuk menjalankan aplikasi pendidikan dalam melakukan maintenance, perubahan data maupun back-up database. Pada Server Aplikasi Akademik, menggunakan database SQL server 2000 sebagai database lokal yang mengelola data akademik. Dengan database local, maka setiap divisi yang memiliki akses database dapat mengakses secara langsung tanpa menggunakan database mysql karena proses kerja relatif lebih lama.

MySQL database merupakan database hosting yang menyediakan fasilitas database MySQL. Database mysql merupakan database yang dapat diakses oleh mahasiswa dan dosen dengan media internet. Data yang terdapat pada database mysql adalah data yang di peroleh dari pengiriman nilai yang dilakukan administrator maupun nilai akhir yang di kirim oleh dosen pengampu matakuliah. Beberapa perusahaan penyedia hosting menyediakan fasilitas database berupa Paket Virtual Private Server (Vps), namun ada juga perusaaan yang menyediakan database secara gratis, contohnya freemysql.net.

\section{B. Hasil Perancangan Sistem Context Diagram}

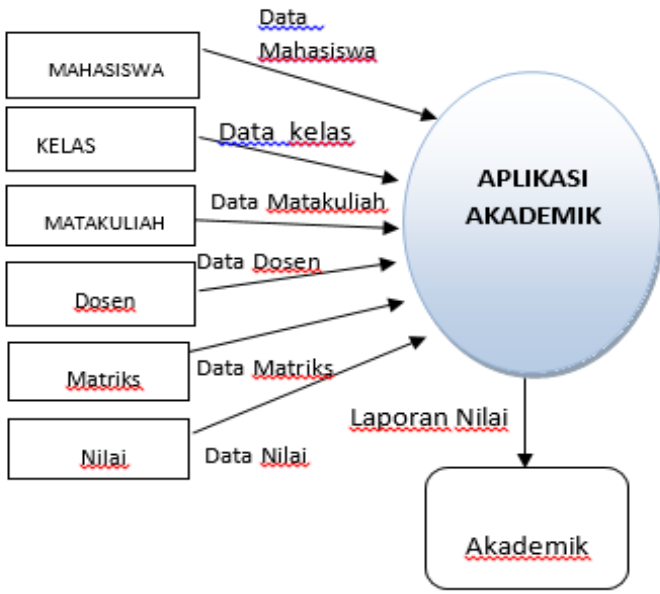

Gbr.2 Context Diagram
Data yang terdapat dalam database mysql antara lain data mahasiswa, kelas, matakuliah, dosen, matriks dan nilai. Dengan input tersebut diharapkan akan menghasilkan laporan akademik berupa laporan nilai, Kartu hasil studi maupun kartu rencana studi yang selanjutnya dapat di gunakan oleh bagian akademik. Mahasiswa,

Data Mahasiwa di peroleh dari bagian pendidikan dan disimpan dalam format atb file menggunakan aplikasi notepad. Data mahasiswa yang tersimpan dalam atb file merupakan data mahasiswa aktif dari tahun ajaran yang sedang berjalan.

Kelas, merupakan data mengenai kelas yang aktif dari tahun ajaran yang berjalan.

Matakuliah, Matakuliah adalah data mengenai matakuliah yang diambil mahasiswa tahun ajaran yang sedang berjalan.

Dosen, adalah pengajar matakuliah pada tahun ajaran berjalan. Sehingga data dosen yang ditampilkan merupakan dosen yang aktif mengampu matakuliah semester berjalan.

Matriks, merupakan data yang mernyimpan jadwal perkuliahan beserta dosen dan kelas masing masing.

Nilai, merupakan data yang menyimpan informasi mengenai perolehan hasil belajar mahasiswa.

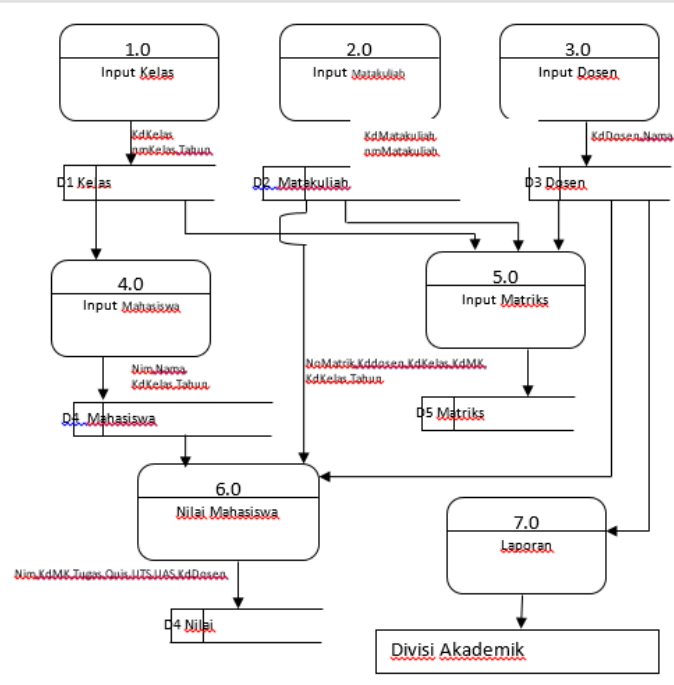

Gbr.3 Data Flow Diagram

Penjelasan Data Flow Diagram

a. Proses 1 ( Input Data Kelas )

Proses ini merupakan proses untuk menginput data-data kelas yang akan Digunakan untuk menentukan kela dari mahasiswa masing masing. Tabel ini berfungsi untuk menampilkan data Kelas yang aktif dari tahun ajaran yang sedang berjalan.

b. Proses 2 ( Input Data Matakuliah)

Proses ini merupakan proses untuk menginput data-data Matakuliah yang akan disimpan kedalam tabel Matakuliah. Tabel ini berfungsi untuk menampilkan data Matakuliah yang dibaca melalui tabel Matakuliah tersebut. 


\section{c. Proses 3 ( Input Data Dosen)}

Proses ini merupakan proses untuk menginput data-data Dosen yang sedang mengajar atau aktif dan akan disimpan kedalam tabel Dosen. Tabel ini berfungsi untuk menampilkan data Dosen yang dibaca melalui tabel Dosen tersebut.

d. Proses 4 ( Input Data Mahasiswa)

Proses ini merupakan proses untuk menginput data-data Mahasiwa yang akan disimpan kedalam tabel Mahaiswa. Tabel ini membutuhkan data kelas yang dismpan dalam table Kelas. Tabel Mahasiswa ini berfungsi untuk menampilkan data Mahasiswa yang dibaca melalui tabel Mahaiswa tersebut.

e. Proses 5 ( Input Data Matriks )

Proses ini merupakan proses untuk menginput data-data Jadwal matakuliah untuk tiap kelas. Tabel ini membutuhkan data kelas, data Dosen dan data matakuliah untuk proses enrty record nya. Tabel Matriks ini berfungsi untuk menampilkan data matriks yang dibaca melalui tabel Matriks tersebut.

f. Proses 6 ( Input Data Nilai)

Proses ini merupakan proses untuk menginput data-data Nilai mahasiswa dan membutuhkan data dari Tabel Mahasiwa, Matakuliah dan Dosen pengampu matakuliah tertentu. Data yang berhubungan dengan table table tersebut akan disimpan kedalam tabel Mahasiswa. Tabel ini berfungsi untuk menampilkan data Nilai, Mahasiswa, Kelas, Matakuliah dan Dosen pengampu matakuliah yang dibaca melalui tabel Nilai tersebut.

g. Proses 7 (Proses data laporan)

Proses dimana menampilkan laporan berupa hasil belajar mahasiswa yang dikelompokkan berdasarkan kelas masing masing. Laporan yang disampaikan ke bagian akademik yaitu file hard copy berupa laporan hasil print Out, sedangkan untuk record yang telah dientry dapat dikirim via internet pada aplikasi penilaian online.

\section{Batasan Implementasi}

Batasan implementasi ini ditinjau agar pengguna dapat mengakses perangkat lunak dengan baik , batasannya adalah sebagai berikut :

a. Segi hardware, PC (Personal Komputer) dengan prosessor yang memiliki clock speed 400 MHZ dan RAM minimal $256 \mathrm{Mb}$ atau memiliki spesifikasi yang lebih baik.

b. Printer, untuk mencetak hasil laporan.

c. Segi software, menggunakan Microsoft Visual Basic, mySQL connector dan Notepad.

Batasan Implementasi Ditinjau dari Server

a. Segi hardware, PC (personal komputer) dengan prosessor yang memiliki clock speed 1.8 GHZ dan RAM minimal 1 GB dan spesifikasi lebih baik maka layanan akan lebih baik.

b. Segi software, menggunkan system operasi Microsoft windows XP, Microsoft Visual Basic, SQL Server 2000.

\section{Implementasi}

Implementasi merupakan tahap dimana system siap dioperasikan pada keadaan yang sebenarnya, dari sini akan diketahui apakah system yang di buat benarbenar dapat menghasilkan tujuan yang diinginkan. Sebelum system diterapkan dan di implementasikan, maka system harus bebas terlebih dahulu dari kesalahan-kesalahan penulisan bahasa, kesalahan waktu proses atau kesalahan logika. Setelah system bebas dari kesalahan, system dites dengan membuka halaman-halaman yang yang ada.

\section{E. Implementasi Database}

Untuk komputer client terlebih dahulu menginstal mysql-connector-odbc-3.51.29 untuk melakukan koneksi database online dan melakukan mengriman record atau mengunduh file database. Namun jika user telah memiliki file table yang dibutuhkan, connector tidak perlu di install. Aplikasi tidak membutuhkan komponen tambahan dan dapat dijalankan dari media penyimpanan portable seperti Flash disk

\section{F. Implementasi Aplikasi Penilaian Hasil Belajar}

Aplikasi dibuat dalam 2 bentuk, yaitu File Aplikasi untuk mahasiswa (client) dan Untuk Administrator (Server). Untuk Aplikasi Dosen terdapat beberapa form. Berikut form yang ada pada aplikasi penilaian hasil belajar berbasis visual ini:

1. Form Menu utama

Form Menu Utama merupakan tampilan yang pertama kali dilihat oleh pemakai saat aplikasi dijalankan. Pada Form utama terdapat 4 menu yang terdiri dari File, Data Master, Informasi dan Peralatan. Form Menu utama ini digunakan untuk menjalankan form lain dan bertindak sebagai induk form yang lain.

2. Form Login

Form login digunakan untuk menyaring user yang akan menjalankan aplikasi, sehingga tidak semua orang dapat mengakses data yang terdapat didalam nya.

3. Form KRS (Kart Rencana Studi)

Form ini berisi informasi mengenai matakuliah yang akan dijalani per semester.

4. Form Mahasiswa

Form mahasiwa berisi informasi mengenai Mahasiswa berupa kelas, tahun masuk hingga data pribadi.

5. Form Kartu Hasil Studi (KHS)

Form KHS berisi informasi mengenai Nilai yang diperoleh mahasiswa dan mencetak KHS berupa pdf file.

6. Form Matriks

Form Matriks berisi informasi mengenai Jadwal mengajar dosen beserta matakuliah dan kelas masing-masing.

7. Form Nilai

Form Nilai berisi informasi nilai mahasiswa yang dapat di upload ke internet sebagai nilai ahir 
mahasiswa. $\mathrm{n}$ beserta matakuliah dan kelas masingmasin

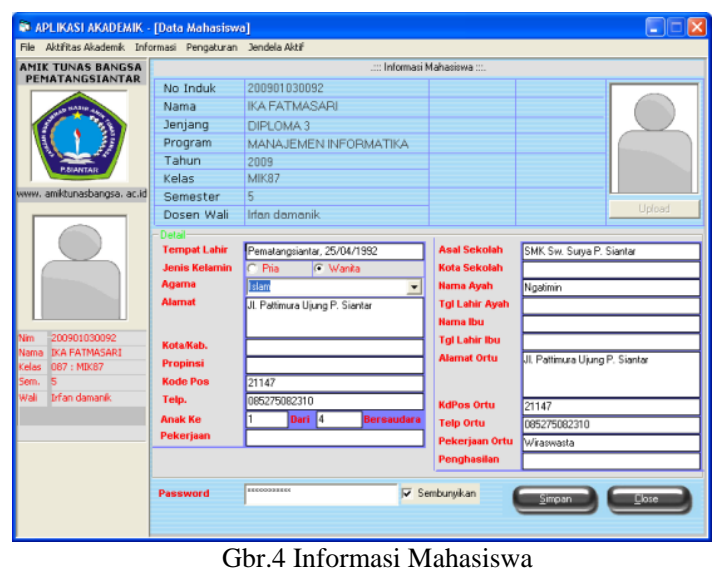

8. Form Browse Nilai

Form Browse Nilai berisi informasi nilai mahasiswa yang telah diproses hingga menghasilkan informasi yang baru. Dari form ini dosen dapat melakukan upload nilai ke database internet yang selanjutnya akan digunakan sebagai data mencetak KHS (Kartu Hasil Studi ) Mahasiswa.

Untuk Melakukan pencetakan terhadap data yang telah entri, Klik button Cetak Pdf, sedangkan untuk upload data yaitu dengan cara klik button kirim Online.

Administrator akan melakukan import data dari Database Online sebagai sumber database sebagai bahan untuk cetak KHS.

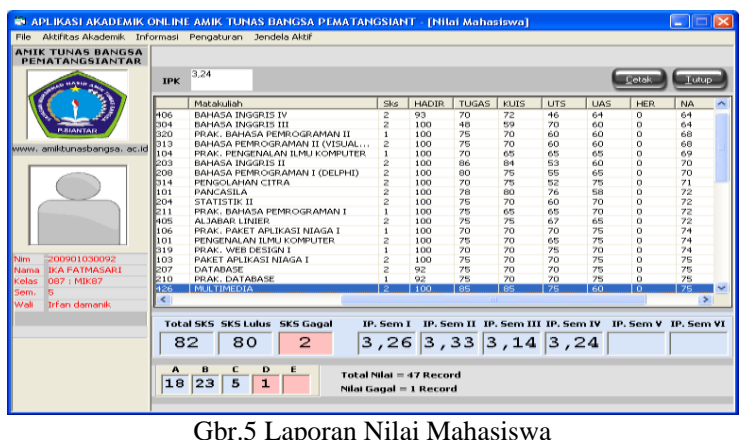

Tampilan database MySql

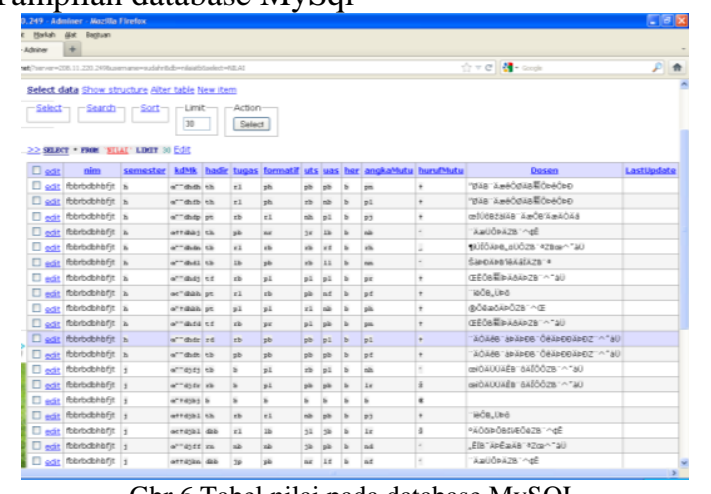

Gbr.6 Tabel nilai pada database MySQL

\section{KESIMPULAN DAN SARAN}

\section{A. Kesimpulan}

Dari hasil penelitian,dapat ditarik beberapa kesimpulan yang dapat dikemukakan sebagai berikut :

1. Aplikasi Penilaian Hasil belajar ini dirancang sebagai solusi bagi pihak AMIK Tunas Bangsa untuk pelayanan informasi akademik. Dengan metode ini mahasiswa juga dapat melihat nilai yang sudah masuk dari internet sehingga tidak perlu dating secara langsung ke divisi database untuk melihat nilai.

2. Aplikasi yang dirancang menggunakan enkripsi data sehingga hanya dapat dibaca dengan menggunakan aplikasi yang penilaian hasil belajar. Dengan cara ini data yang tersimpan lebih aman.

3. Aplikasi ini dibuat sebagai sarana informasi dalam menyajikan informasi akademik yang bersifat online bagi kalangan mahasiswa.

\section{B. Saran}

Dalam sistem ini disadari masih banyak kekurangan dan kelemahan, oleh karena itu untuk pengembangan selanjutnya disarankan:

1. Untuk pengembangan selanjutnya diharapkan dapat memberikan informasi atau laporan data-data yang lebih meluas dalam bentuk grafik nilai mahasiswa ataupun membuat interaksi mahasiswa dengan dosen pengampu matakuliah.

2. Hendaknya dalam penginputan data nilai diperhatikan ketelitiannya sehingga tidak terdapat kesalahan dalam penyampaian informasi kepada pihak yang memerlukan informasi tersebut.

\section{REFERENSI}

[1] Manduro, Budi A. 2011. "Pengembangan Sistem Informasi LAPAS Narkoba untuk menunjang pengungkapan kasus narkoba di lembaga pemasyarakatan pada puslitbang dan info Badan Narkotika Nasional. Vol I no. 12011.

[2] Alter, S. 1999. Information system: A Magement Perspective, 3rd ed., Upper Saddle River, NJ: Prentice Hall

[3] Jogiyanto HM, Analisis dan Desain Sistem Informasi, Penerbit ANDI Yogya, Yogyakarta, 1997

[4] Yuniar Supardi, Seri Pemrograman Visual Basic Dalam Praktek, Penerbit DATAKOM, Jakarta, 2002.

[5] Sutabri Tata, Analisa Sistem Informasi, Penerbit Andi, Yogyakarta, 2004

[6] Madcoms, Database Visual basic 6.0 dengan SQL, Penerbit Andi, Yogyakarta, 2003.

[7] Suja Iman, Pemrograman SQL dan Database Server MySQL, Penerbit Andi, Yogyakarta, 2005

[8] Al-Fatta Hanif, Analisis dan Perancangan Sistem Informasi, Penerbit Andi, Yogyakarta, 2007

[9] Nugroho Adi, Analisis dan Perancangan Sistem Informasi dengan Metodologi Berorientasi Objek, Penerbit Informatika Bandung, Bandung, 2002

[10] Wahana Komputer, Pemrograman Visual Basic 6.0, Penerbit Andi, Yogyakarta, 2000

[11] Tajudin, M. A. Manan,Agus P, Yoyok A. 2007. Rancang Bangun Aplikasi sarana prasarana pendidikan berbasis sekolah secara online di kota Mataram dan Lombok Barat, Universitas Indonesia, Jakarta 